\title{
Komisi Pemberantasan Korupsi Menjadi Objek Hak Angket Dewan Perwakilan Rakyat (Analisis Yuridis Terhadap Putusan Mahkamah Konstitusi Nomor 36/PUU-XV/2017 Dan Undang-Undang MD3)
}

\author{
Paman Nurlette \\ Program Magister Ilmu Hukum Universitas Indonesia, Jakarta, Indonesia \\ E-mail:nurlettepaman@gmail.com
}

\begin{abstract}
The style of building our constitutional legal system today is very varied, it has implications for the shifting functions and rights of the State organs including the State organs of the Republic of Indonesia House of Representatives. To understand the conception of the functions and rights of the organs of the Republic of Indonesia Representative Council (DPR RI), it is seen as two sides of a coin (two sides of one coin). The DPR RI's inquiry right is a supervision that must be carried out on policies implemented by the executive. The KPK is an organ that is within the executive family, because it carries out investigations, investigations and prosecutions of corruption cases, such as those carried out by the Prosecutors' Office and the Police. Thus if the KPK is referred to as part of the judiciary. The task of investigation, investigation and prosecution is the task of the executive, not the legislative and judiciary. In addition, the KPK has been an institution that uses the State budget, so it should be overseen by the DPR. if the $D P R$ cannot exercise the right to question the KPK on the grounds of independence. The reason is, it is not right to refuse the right to question the KPK. With the decision of the Constitutional Court (MK) in the main essence of the decision which positions the KPK in institutions that are in the realm of power, the executive for carrying out the task of investigation, investigation and prosecution in corruption, which is actually the same as the authority of the police and prosecutors. The KPK is a state institution that is within the executive power cluster, so the KPK can be the object of using the DPR's questionnaire right as the people's representative who carries out the supervisory function. But the use of the questionnaire right by the DPR cannot be applied in the case that the KPK is carrying out its investigative, investigative and prosecution tasks. This means that the KPK cannot be carried out while the KPK is carrying out its duties.
\end{abstract}

Keywords: Corruption Eradication Commission; Questionnaire Rights; People's Representative Council.

\section{A. PENDAHULUAN}

Fungsi dan hak DPR ibarat dua sisi dari sekeping mata uang (two sides of one coin). Dapat dibedakan tetapi tidak terpisahkan. Antara keduanya, mana yang lebih dulu diadakan? Mengikuti pendapat J.H.A. Logemann, fungsi atau yang lazim disebut dalam 
hukum tata negara dengan jabatan adalah lingkungan kerja. Ia dibentuk karena adanya pembagian kerja yang sifatnya tertentu dan terus menerus untuk mencapai tujuan bersama atau tujuan negara. Fungsi hanya dapat bergerak mencapai sasaran atau tujuan, apabila ada pemangku jabatan, yaitu pejabat sebagai orang perorangan (natuurlijkpersoon) yang duduk atau didudukkan dalam suatu jabatan dengan wewenang untuk merealisasikan jabatan tertentu. Agar wewenang dapat dilaksanakan dalam suatu tindakan konkrit dan dapat dipertanggungjawabkan (baik secara politik, hukum, atau sosial), kepada pejabat dibekali hak dan kewajiban (recht en plicht) tertentu. ${ }^{1}$

Tanpa hak dan kewajiban, segala wewenang tidak dapat diwujudkan secara konkret dalam bentuk tindakan-tindakan, baik tindakan hukum atau tindakan konkret tertentu (recht en feitelijke handelingen). Dalam melaksanakan fungsinya, sesuai dengan yang diatur dalam Pasal 20A Ayat (2) UUD NRI Tahun 1945 DPR memiliki hak interpelasi, hak angket, dan hak menyatakan pendapat. Untuk memahami mengenai hak angket DPR, hak angket menurut Pasal 79 ayat (3) Undang-Undang Nomor 17 Tahun 2014 Junto Undang-Undang Nomor 13 Tahun 2019 tentang Majelis Permusyawaratan Rakyat, Dewan Perwakilan Rakyat, Dewan Perwakilan Daerah, Perwakilan Rakyat Daerah adalah hak DPR untuk melakukan penyelidikan terhadap pelaksanaan suatu undang-undang dan/atau kebijakan Pemerintah yang berkaitan dengan hal penting, strategis, dan berdampak luas pada kehidupan bermasyarakat, berbangsa, dan bernegara yang diduga bertentangan dengan peraturan perundang-undangan. ${ }^{2}$

MenurutSal di Isra, landasan untuk memahami peranan DPR dalam mengaktualisasikan aspirasi rakyat tidak lain merupakan perwujudan dari tiga fungsi utama dan strategis yang dimilikinya, yaitu di bidang perundang-undangan, di bidang anggaran, maupun di bidang pengawasan. ${ }^{3}$ Sebelum membahas mengenai gagasan tentang bagaimanakah keberadaan hak angket dalam melaksanakan fungsi pengawasan DPR terhadap KPK, perlu kita pahami terlebih dahulu mengetahui alasan mengapa DPR menggunakan hak angket tersebut terhadap KPK. Kinerja KPK selama ini mendapatkan penilaian yang baik dari masyarakat. Namun, hal tersebut tidak berarti bahwa prinsip transparansi dan akuntabilitas tidak perlu lagi menjadi perhatian, atau pengawasan tidak diperlukan lagi. Terlebih soal kaitannya dengan pelaksanaan tupoksi KPK.

DPR dalam hal ini Komisi III mendapatkan masukan dan informasi tentang tidak selalu berjalannya pelaksanaan tupoksi KPK tersebut, sesuai peraturan perundangundangan dan tata kelola kelembagaan yang baik. Dalam laporan hasil pemeriksaan (LHP) kepatuhan KPK tahun 2015 mengenai tata kelola anggaran, terdapat 7 indikasi ketidakpatuhan terhadap peraturan perundang-undangan, diantaranya: ${ }^{4}$

1) Kelebihan pembayaran gaji pegawai KPK yang belum diselesaikan atas pelaksanaan tugas belajar

2) Belanja barang pada direktorat monitor kedeputian informasi dan data yang tak dilengkapi dengan pertanggungjawaban yang memadai dan tak sesuai mata anggarannya.

3) Risalah sidang Dewan Perwakilan Rakyat Indonesia (Laporan Pelaksanaan Fungsi, Tugas, dan Wewenang DPR RI pada Sidang Tahunan MPR RI) Tahun Kelima 2003-2004.

1 J.H.A, Logemann. (1985) Over De Theorie Van Enn Stelling Staatrecht, Jogyakarta : Gajah Mada,.

2 Lihat Pasal 79 ayat (3) Undang-Undang No. 17 Tahun 2014 tentang Majelis Permusyawaratan Rakyat, Dewan Perwakilan Rakyat, Dewan Perwakilan Daerah dan Dewan Perwakilan Rakyat Daerah

3 Isra, Saldi. (2010). Pergeseran Fungsi Legislatif Menguatnya Model Legislasi Parlementer Dalam Sistem Presidensial Indonesia, Jakarta : PT Raja Grafindo Persada. h.2.

4 Ibid. h, 58. 
4) Pembayaran belanja perjalanan dinas, belanja sewa, belanja jasa profesi pada biro hukum.

5) Kegiatan perjalanan dinas kedeputian penindakan yang tak didukung surat perintah.

6) Standar biaya pembayaran atas, honorarium kedeputian penindakan, realisasi belanja perjalanan dinas biasa tak sesuai dengan ketentuan minimal dan

7) Perencanaan gedung KPK tidak cermat sehingga mengakibatkan kelebihan pembayaran.

Selain terkait tata kelola anggaran, sebagaimana di ketahu bahwa, Komisi III juga mendapatkan masukan serta informasi terkait tentang tata kelola dokumentasi dalam proses hukum penindakan dugaan korupsi. Seperti terjadi pembocoran dokumen dalam proses hukum tersebut seperti BAP, sprindik dan surat cekal, terdapat dugaan ketidakcermatan dan ketidakhati-hatian dalam penyampaian keterangan dalam proses hukum maupun komunikasi publik, serta dugaan pembocoran informasi ke media tertentu sehingga beredar nama yang kebenarannya belum dikonfirmasikan secarajelas. Selain itu Komisi III juga mendapat informasi bahwa ada terjadi perpecahan internal di tubuh KPK. Kemudian ada elemen masyarakat juga menyampaikan adanya ketidakharmonisan bahkan sikap insubkoordinasi dari kalangan internal dengan pimpinannya komisioner KPK.

Pokok materi angket menurut penulis, merupakan kewajiban DPR untuk menjaga keberadaan KPK agar tidak hanya kuat dalam melaksanakan tupoksinya namun juga KPK lebih cermat dan memperhatikan seluruh ketentuan hukum maupun HAM dan menerapkan prinsip transparansi dan akuntabilitas yang benar dalam tata kelola termasuk terkait penggunaan anggaran. Serta adanya penyempurnaan terhadap pelaksanaan tugas dan wewenang KPK dalam penegakan hukum yang adil, transparan, akuntabel, profesional, proporsional sesuai ketentuan peraturan perundang-undangan. Usul hak angket saat itu telah diketok oleh mantan Wakil Ketua DPR Fahri Hamzah meski mendapat penolakan keras lewat interupsi anggota dari sejumlah Fraksi di DPR RI. Namun setelah usulan tersebut disetujui, maka fraksi-fraksi akan diminta mengirim perwakilan untuk pansus angket KPK saat itu. Hak angket pertama kali mencuat dalam rapat dengar pendapat antara KPK dan Komisi Hukum DPR. Ketika itu Komisi meminta KPK membuka rekaman pemeriksaan Miryam Haryani. ${ }^{5}$

KPK saat itu tetap menolak membuka rekaman BAP Miryam sehingga pada akhirnya berujung pada Pengajuan hak angket oleh DPR. Sebagimana diketahui bahwa, ada dua kasus berbeda yang melibatkan Miryam, yakni, pertama sebagai saksi dalam kasus dengan tersangka Irman Gusman dan Sugiharto, yang kedua kasus yang menjerat Miryam sebagai tersangka dalam memberi keterangan palsu. Oleh karena itu BAP Miryam untuk kasus kedua yang diminta DPR untuk dibuka. Namun KPK tetap menolak rekaman pemeriksaan tersebut dibuka karena kasus masih belum sampai di pengadilan dan hanya bisa dibuka ketika proses pengadilan berlangsung. Selain itu seperti diketahui, penyidik KPK Novel Baswedan dituding telah melakukan intimidasi dalam proses pemeriksaan. dalam persidangan, Novel mengatakan bahwa Miryam selaku anggota DPR mendapat tekanan dari sejumlah anggota DPR lainnya saat dimintai keterangan dalam pemeriksaan, ia mengaku di tekan oleh sejumlah anggota DPR terkait kasus korupsi e-

${ }^{5}$ https://kumparan.com/@,kumparan-news/tanggapan-kpk-atas-10-rekomendasi-pansus-hak angketdpr. 28 Juli 2018 (22.30). KPK. 2018. KPK Sebut Lembaga Pengawas Usulan Pansus Angket Mengadaada. 
KTP.

Dengan demikian dari uraian di atas penulis menilai bahwa, upaya Komisi III DPR dalam mendesak KPK untuk membuka rekaman pemeriksaan terhadap Miryam Haryani merupakan sebuah bentuk intervensi politik terhadap proses penegakan hukum. Upaya tersebut juga bentuk penggiringan proses penegakan hukum ke dalam proses politik. Sebagai komisi yang membidangi masalah hukum, Komisi III seharusnya memahami konsepsi pemeriksaan terhadap Miryam berlangsung dalam rangka penegakkan hukum (pro justitia). Kontrol dalam kasus tersebut seharusnya dilakukan di pengadilan sebagai bentuk mekanisme hukum, bukan oleh Komisi III. Karena Pengadilan telah menghadirkan penyidik KPK di persidangan. Namun di sisi lain KPK juga telah menetapkan yang bersangkutan sebagai tersangka, yang artinya bahwa proses penegakan hukum dan kontrol telah berjalan sesuai rel-rel hukum yang berlaku.

Dalam hal ini sebenarnya tidak diperlukan adanya keterlibatan Komisi III DPR dalam kasus tersebut. Apabila memang diperlukan kontrol pada proses hukum tersebut, maka pengadilan yang akan bertindak secara independen dan akan mengkonfirmasi segala sesuatu yang telah dituangkan dalam BAP. Menurut penulis dari optik ketatanegaraan sebelum adanya Putusan Mahkama Konstitusi Nomor 36/PUU-XV/2017. Pengajuan hak angket itu merupakan langkah yang tidak sah secara yuridis. Musababnya, Pasal 79 ayat (3) Undang-Undang Nomor 17 Tahun 2014 Junto Undang-Undang Nomor 13 Tahun 2019 tentang MPR, DPD, DPR, dan DPRD (MD3) menyatakan DPR hanya boleh melakukan hak angket kepada lembaga pemerintah. Sehingga dalam hal ini tidak tepat kiranya apabila hak angket dikenakan kepada KPK, karena KPK bukanlah lembaga pemerintah namun KPK merupakan lembaga Negara yang bersifat independen.

\section{B. METODE PENELITIAN}

Penelitian ini akan dilakukan menggunakan jenis metode yuridis normatif. Dengan pendekatan masalah melalui pendekatan perundang-undangan dan pendekatan dengan bahan hukum primer dan bahan hukum sekunder, serta bahan non hukum kemudian dilanjutkan dengan analisa bahan hukum. .Jenis bahan Hukum dan langkah-langkah yang diambil untuk melakukan penulisan ini adalah menggunakan bahan kajian berupa: ${ }^{6}$ Bahan Hukum Primer, Bahan hukum primer adalah bahan pustaka yang berisikan pengetahuan ilmiah yang baru atau mutakhir ataupun pengertian baru tentang fakta yang diketahui maupun mengenai suatu gagasan. Bahan-bahan hukum primer terdiri perundang-undangan, catatan-catatan resmi atau risalah dalam pembuatan perundangundangan dan putusan-putusan hakim. ${ }^{7}$

Dalam penelitian ini bahan hukum primer terdiri dari: Undang-Undang Dasar Negara Republik Indonesia Tahun 1945, Undang-Undang Dasar Republik Indonesia Tahun 1945 Setelah Perubahan, Undang-Undang Nomor 17 Tahun 2014 junto, UndangUndang Nomor 13 Tahun 2019 tentang Majelis Permusyawaratan Rakyat, Dewan Perwakilan Rakyat, Dewan Perwakilan Daerah, dan Dewan Perwakilan Rakyat Daerah, Undang-Undang Nomor 14 Tahun 2008 tentang Keterbukaan Informasi Publik, UU Nomor 6 Tahun 1954 tentang Penetapan Hak Angket DPR, Putusan MK Nomor 012-0161019/PUU-IV/2006, Putusan MK Nomor 8/PUU-VIII/2010, Putusan MK Nomor 36/PUU-XV/2017, Putusan MK Nomor 37/PUU-XV/2017 dan Putusan MK Nomor 40/PUU-XV/2017. Bahan Hukum Sekunder, Untuk mendapatkan pemahaman teoritis

\footnotetext{
6 Soekanto, Soerjono. (1986). Pengantar Penelitian Hukum, Jakarta: UI Press, h. 45.

7 Ali, Zainudin. (2009). Metode Penelitian Hukum. Jakarta: Sinar Grafika, h. 23
} 
dan konseptual yang lebih mendalam penelitian ini akan lebih banyak menggunakan sumber-sumber informasi yang berasal dari buku-buku, pendapat ahli atau sarjana hukum, surat kabar, media internet, jurnal hasil penulisan atau hasil seminar maupun dokumen dan serta keterangan-keterangan lainnya yang mendukung kajian penulisan hukum ini. Bahan Hukum Tersier. Yaitu bahan-bahan hukum yang merupakan penjelasan terhadap bahan hukum primer dan sekunder, seperti kamus dan insklopedia. ${ }^{8}$

\section{PEMBAHASAN}

\section{Tinjaun yuridis hak angket DPR terhadap KPK}

Hak angket merupakan salah satu hak yang dimiliki DPR. Oleh karena itu menurut penulis, Hak DPR RI melekat atau dilekatkan pada fungsi atau jabatan DPR. Karena itu, hak angket diletakkan sebagai hak institusi atau hak kelembagaan. Penggunaan hak kelembagaan utamanya hak angket menjadi petunjuk berfungsinya DPR. Pengertian Hak angket adalah perangkat untuk merealisasikan fungsi DPR. Selain hak kelembagaan, Hak angket merupakan salah satu hak yang dimiliki oleh DPR. Selain hak kelembagaan, hak perseorangan (anggota) juga menjadi alat untuk merealisasikan melaksanakan fungsi DPR seperti hak mengajukan usul rancangan undang-undang, hak mengajukan pertanyaan, hak menyampaikan usul dan pendapat.

Hak angket adalah merupakan hak untuk mengetahui keadaan pemerintahan baik dalam rangka mengetahui pelaksanaan pemerintahan maupun untuk mencari bahanbahan untuk merumuskan kebijakan, atau untuk memberikan suatu persetujuan atau pertimbangan mengenai orang, keadaan atau suatu peristiwa. Dengan demikian Menurut Miranda R.A, hak angket bukan hak untuk mengetahui mengenai kemungkinan telah terjadi tindak pidana atas suatu kasus. Hak angket sebagaimana termaktub dalam Pasal 79 ayat (3) Undang-Undang Nomor 17 Tahun 2014 Junto Undang-Undang Nomor 13 Tahun 2019 yang menyebutkan 'Hak angket, adalah hak DPR untuk melaksanakan penyelidikan terhadap pelaksananaan suatu Undang-Undang dan/atau kebijakan Pemerintah yang berkaitan dengan hal penting, strategis, dan berdampak luas pada kehidupan bermasyarakat, berbangsa, dan bernegara yang diduga bertentangan dengan peraturan perundang-undangan'. ${ }^{9}$

Menurut penulis bahwa, terkait dengan rumusan ketentuan ini memang tidak bersangkutan dengan pelaksanaan fungsi legislasi. Sehingga tidak mengherankan apabila eksistensi hak angket dianggap tidak bersangkutan dengan pelaksanaan fungsi legislasi. Padahal hak mestinya dapat dipergunakan sebagai sarana melakukan evaluasi, menemukan gagasan untuk menciptakan atau mengubah sebuah Undang-Undang yang ada. Karena hak angket tidak pernah dipergunakan untuk mencari bahan-bahan untuk merumuskan kebijakan, DPR kerapkali kehilangan ide dan gagasan, kesulitan menggunakan hak mengajukan usul rancangan Undang-Undang. Selain untuk kepentingan legislasi, hak angket juga ditujukan untuk menyeldiki pelaksanaan tugas pemerintahan dan pembelanjaan Negara. Kalau berpegang pada ketentuan rumusan Pasal 79 ayat (3) Undang-Undang Nomor 17 Tahun 2014 Junto Undang-Undang Nomor 13

${ }^{8}$ Koentjaraningrat, Metode-Metode Penelitian Masyarakat, Gramedia Pustaka Utama, h. 21. 60

${ }^{9}$ Miranda, R.A. (2009). Kedudukan Komisi Independen Sebagai Auxiliary Institutions dan Relevansinya Dalam Struktur Ketatanegaraan Indonesia. Jurnal Konstitusi, kerja sama MK dan PSKN FH Universitas Padjadjaran 1 (1): 53-71. KPK. 2018. Tanggapan KPK Atas 10 Rekomendasi Pansus Hak Angket DPR. 
Tahun 2019, maka hak angket ditujukan untuk menyelidiki pelaksanaan suatu UndangUndang dan/ atau kebijakan pemerintah yang diduga dapat bertentangan dengan Peraturan perundang-undangan yang berlaku.

Hak Angket Dewan Perwakilan Rakyat adalah sebuah hak untuk melakukan penyelidikan yang di miliki oleh Dewan Perwakilan Rakyat (DPR) yang memutuskan bahwa pelaksanaan suatu Undang-Undang dalam kebijakan pemerintah yaitu berkaitan dengan hal penting, strategis, dan berdampak luas pada kehidupan bermasyarakat, berbangsa, bernegara bertentangan dengan ketentuan Peraturan perundang-undangan. Dalam Undang-Undang No.6 Tahun 1954 tentang Hak Angket Dewan Perwakilan Rakyat, maka sekurang-kurangnya jumlah 10 orang anggota DPR yang bisa menyampaikan usulan angket kepada pimpinan DPR. Dalam usulan tersebut harus di sampaikan secara tertulis, di sertai daftar nama dan tanda tangan pengusul serta nama fraksinya. Oleh karena itu usul di nyatakan dalam suatu rumusan yang jelas tentang hal yang akan di selidiki, di sertai dengan penjelasan dan rancangan biaya.

Oleh karena itu panitia angket dalam melaksanakan tugas penyelidikan dengan meminta keterangan dari pemerintah dan pejabatnya, saksi, pakar, organisasi profesi, semua pihak terkait lainnya. Bila dalam sidang paripurna DPR memutuskan bahwa pelaksanaan suatu undang-undang dalam kebijakan pemerintah yang berkaitan dengan hal penting, strategis, dan berdampak luas pada kehidupan bermasyarakat, berbangsa, bernegara bertentangan dengan ketentuan Peraturan perundang-undangan maka DPR dapat menggunakan hak menyatakan pendapat kemudian usul hak angket di nyatakan selesai dan materi angket tersebut tidak dapat di ajukan kembali. Pasal 79 ayat (3) Undang-Undang Nomor 17 Tahun 2014 Junto Undang-Undang Nomor 13 Tahun 2019 DPR mempunyai hak :

a) Interpelasi;

b) Angket; dan

c) Menyatakan pendapat.

Menurut Pakar hukum tata Negara, Yusril Ihza Mahendra, menganggap Dewan Perwakilan DPR (DPR) berwenang dalam membentuk panitia khusus hak angket terhadap Komisi Pemberantasan Korupsi (KPK). Pembentukan pansus dianggap memiliki legalitas karena sesuai tugas dan wewenang parlemen dalam melakukan pengawasan terhadap pelaksanaan Undang-Undang (UU). DPR dapat melakukan angket terhadap KPK karena KPK dibentuk dengan Undang-Undang, sehingga hak angket merupakan pengawasan yang harus dilakukan terhadap kebijakan yang dilakukan lembaga eksekutif. Di lihat dari fungsi dan kewenangannya maka KPK merupakan lembaga eksekutif, karena melakukan penyelidikan, penyidikan, dan penuntutan kasus korupsi, fungsi dan kewenangan tersebut sama halnya seperti yang dilakukan oleh Kejaksaan dan Kepolisian. Apabila KPK disebut sebagai bagian dari yudikatif. Tugas penyelidikan, penyidikan, dan penuntutan adalah tugas eksekutif, bukan legislatif dan yudikatif, Selain itu, KPK selama ini merupakan lembaga yang menggunakan anggaran Negara, sehingga selayaknya diawasi oleh DPR. ${ }^{10}$

${ }^{10}$ Yusril, I.M. (2018). Menurut Yusril Hak Angket Bisa Ditujukan Untuk Semua Lembaga. https://nasional.kompas.com/read/2017/09/14/17595501/menurut-yusril-hak-ang-ket bisaditujukan-untuksemua-lembaga. 15 Juli 2018 (20.00). 


\section{Analisis Materi Pokok Putusan MK Dan Bunyi Putusan Hakim}

Berdasarkan Putusan Mahkamah Konstitusi (MK) yang terkait dengan uji materi hak angket KPK pada Pasal 79 ayat (3) Undang-Undang Nomor 17 Tahun 2014 Junto Undang-Undang Nomor 13 Tahun 2019 tentang MPR, DPR, DPD, DPRD (MD3). "Banyak pendapat kontroversial yang beredar di masyarakat sehingga mengaburkan pemahaman terhadap putusan itu sendiri dan membuat konsepsi yang tidak tepat, karena membingungkan atau bahkan bertentangan dengan esensi dan semangat dari putusan itu. Menimbulkan kerancuan pehaman yang tidak tepat menyangkut lembaga peradilan konstitusi, dalam Putusan MK No. 36/PUU-XV/2017 pada pokoknya menolak permohonan Pemohon menyangkut inkonstitusionalitas Pasal 79 ayat (3) UU MD3, khususnya frasa pelaksanaan suatu undang-undang dan/atau kebijakan Pemerintah secara bersyarat sepanjang dimaknai lain selain yang secara eksplisit termaktub dalam norma tersebut dan Penjelasannya, yakni hak angket hanya terbatas pada lingkup kekuasaan eksekutif."

Oleh karena itu esensi pokok dari putusan tersebut adalah memposisikan KPK dalam lembaga yang berada di ranah kekuasaan eksekutif, KPK merupakan organ Negara yang berada di rumpun kekuasaan eksekutif, maka KPK dapat menjadi obyek penggunaan hak angket DPR sebagai wakil rakyat yang melaksanaan fungsi pengawasan. Tetapi penggunaan hak angket oleh DPR tidak dapat diterapkan dalam hal KPK sedang menjalankan tugas penyelidikan, penyidikan, dan penuntutan. Artinya bahwa KPK itu tidak bisa diangket ketika KPK sedang menjalankan tugasnya. Karena berkaitan dengan independensi dan bebasnya KPK dari pengaruh kekuasaan mana pun adalah dalam melaksanakan tugas dan wewenangnya, dengan demikian menurut penulis bahwa Putusan MK tersebut, telah bertentangan dengan Putusan terdahulu yakni (1) Putusan No. 012-016-019/PUU-IV/2006 (2) Putusan Nomor 5/PUU-IX/2011, dan (3) Putusan No. 49/PUU-XI/2013. Dari esensi beberapa Putusan tersebut sehingga MK tidak pernah berpendapat yang menyatakan KPK lembaga Negara yang berada pada rumpun kekuasaan legislatif, eksekutif atau yudikatif. Baru pada beberapa Putusan di atas Mahkamah berpendapat KPK merupakan organ Negara yang berada di rumpun kekuasaan eksekutif.

Dalam ketiga putusan tersebut pada pokoknya Mahkamah Konstitusi menyatakan bahwa, KPK merupakan lembaga Negara yang terkait/melaksanakan sebagian fungsi kekuasaan kehakiman. Oleh karena itu menurut penuis bahwa, posisi KPK sebagai lembaga Negara yang bukan termasuk dalam ranah kekuasaaan kehakiman namun diberikan tugas, kewenangan, dan fungsi yang berkaitan dengan fungsi kekuasaan kehakiman. Maka pada Putusan No. 012-016-019/PUU-IV/2006 terdapat pemahaman bahwa Undang-Undang No. 30 Tahun 2002 KPK junto Undang-Undang Nomor 19 Tahun 2019 secara institusional berada di ranah kekuasaan kehakiman. Ini mengingat legitimasi eksistensi Pasal 53 menyatakan. Dengan Undang-Undang ini dibentuk Pengadilan Tindak Pidana Korupsi yang bertugas dan berwenang memeriksa dan memutus tindak pidana korupsi yang penuntutannya diajukan oleh Komisi Pemberantasan Korupsi.

Untuk itu dengan ketentuan kompetensi Pengadilan Tipikor sangat ditentukan oleh lembaga yang menuntut tersebut, yaitu KPK Sebab Pengadilan Tipikor dirancang diletakkan dalam wilayah berkiprahnya kewibawaan KPK. Namun mengacu pada Pasal 53 dinyatakan bertentangan dengan UUD 1945 secara limitatif. Maka tetap mempunyai kekuatan hukum mengikat sampai diadakan perubahan paling lambat 3 (tiga) tahun terhitung sejak putusan diucapkan. Artinya bahwa pengaturan mengenai pembentukan Pengadilan Tipikor harus dengan sebuah Undang-Undang tersendiri bukan di dalam Undang-Undang KPK. Sehingga dengan adanya Putusan Nomor. 012-016-019/PUU-

81 I S A S Vo1.26 No.1, Januari-Maret 2020 
IV/2006 mengukuhkan KPK sebagai organ Negara di ranah eksekutif. oleh karena itu di mana kekuasaan eksekutif adalah kewenangan penyelidikan, penyidikan, dan penuntutan dalam perkara tindak pidana korupsi. Sementara kekuasaan yudikatif adalah kewenangan Pengadilan Tipikor yang mengadili dan memutus perkara tindak pidana korupsi. ${ }^{11}$

Di sisi lain dilihat dari presfektif yuridis normatif bahwa, tidak terdapat dasar dan alasan untuk menyebut Putusan itu bertentangan dengan putusan Mahkamah sebelumnya. Menurut penulis justru Putusan tersebut sangat sejalan dan melengkapi putusan sebelumnya. Sehingga Mahkamah pada satu sisi menegaskan hak angket sebagai hak konstitusional DPR untuk melakukan fungsi pengawasan khususnya dalam pemberantasan tindak pidana korupsi yang dilakukan KPK. Namun di sisi lain Mahkamah menguatkan lembaga KPK Sebab meskipun menjadi obyek hak angket DPR akan tetapi hak angket dibatasi bukan pada tugas dan kewenangan yudisial KPK yaitu penyelidikan, penyidikan, dan penuntutan dalam perkara dugaan tindak pidana korupsi. Putusan tersebut sama sekali bukan merupakan upaya pelemahan terhadap KPK. Melainkan Mahkamah justru menegaskan KPK sebagai organ Negara yang dalam menjalankan tugas dan wewenannya bersifat independen.

Sebagaimana diketahui Mahkamah Konstitusi terbelah dalam menolak permohonan uji materi yang diajukan oleh sejumlah pegawai Komisi Pemberantasan Korupsi terhadap Hak Angket KPK. Yakni Lima hakim menyatakan menolak permohonan para pemohon dan menyatakan bahwa hak angket KPK yang dibentuk oleh Dewan Perwakilan Rakyat adalah sah. Oleh karena itu MK nyatakan Hak Angket sudah sah dalam uji materi tersebut. Pegawai menilai pembentukan hak angket itu tak sesuai dengan apa yang di amanatkan dalam rumusan norma Pasal Pasal 79 ayat (3) Undang-Undang Nomor 17 Tahun 2014 Junto Undang-Undang Nomor 13 Tahun 2019. Para Pemohon menganggap bahwa KPK bukan termasuk ranah ataupun unsur eksekutif sehingga tidak dapat dijadikan sebagai Objek dan Subjek daam pelaksana hak angket oleh DPR.

Dalam pertimbangannya Mahkamah Konstitusi menyatakan bahwa, KPK adalah lembaga penunjang yang dibentuk oleh berdasarkan Undang-Undang. Dengan demikian KPK adalah lembaga eksekutif. Sementara empat hakim Konstitusi lainnya menyatakan disssenting opinion atau perbedaan pendapat atas putusan tersebut. Dalam pertimbangannya keempat hakim tersebut menyatakan bahwa KPK adalah lembaga independen sehingga tidak termasuk wilayah eksekutif. Dengan demikian harusnya DPR tidak bisa menggunakan hak angket terhadap KPK, namun pada kenyataanya bahwa Mahkamah Konstitusi menilai KPK masuk ke dalam ranah eksekutif. Oleh sebab itu DPR dinilai sudah berhak menggunakan hak angket terhadap KPK. Hakim juga menilai DPR berhak meminta pertanggungjawaban dari KPK sebagai pelaksanaan tugas kewenangannya. Meskipun KPK disebut sebagai lembaga independen.

Menimbang walaupun dikatakan KPK independen dalam arti bebas dari pengaruh kekuasaan lain, namun DPR sebagai wakil rakyat berhak meminta pertanggungjawaban pelaksanaan tugas dan kewenangan KPK, Namun meskipun menolak permohonan pemohon soal hak angket DPR terhadap KPK. Dalam putusan tersebut terdapat lima orang hakim Konstitusi yang berpendapat MK merupakan lembaga eksekutif. Namun empat hakim lainya menyatakan dissenting opinion. Tetapi dari empat hakim tersebut terdapat satu Hakim Konstitusi Maria Farida Indrati mempunyai alasan berbeda dengan 3 Hakim Konstitusi lainnya. Dengan demikian meski putusan tersebut berlaku mengikat namun putusan Mahkamah yang memuat legal policy yang memperbarui politik hukum

11 Ibid, h. 42.

82 |S A S I Vo1. 26 No.1, Januari-Maret 2020 
lama yang dirumuskan oleh Pembentuk Undang-Undang. ${ }^{12}$

Dengan kata lain, legal policy lama dikesampingkan dan telah diganti dengan legal policy baru yang dirumuskan oleh Mahkamah melalui putusannya. Serta hal demikian tidak relevan dengan memperdebatkan putusan tersebut, oleh karena itu putusan MK tersebut tidak ada hubunganya dengan kepentingan sepihak pimpinan KPK itu sendiri. Menurut penulis bahwa dengan menjadikan KPK masuk dalam rumpun eksekutif, maka DPR dapat melakukan angket terhadap lembaga KPK tersebut. Meski pun dalam putusan MK angket terhadap KPK dikecualikan terhadap tindakan penyelidikan, penyidikan dan penuntutan dalam penanganan perkara korupsi, namun independensi KPK merupakan hal wajar Sebab terjadi perkembangan pembagian kekuasaan dalam sistem ketatanegaraan. Dan hal ini Menjadi aneh karena dalam putusan MK No.36-40/PUU-XV/2017 hanya membagi kekuasaan menjadi tiga. Yakni eksekutif, legislatif dan yudikatif.

Padahal dalam perkembangan suatu sistem ketatanegaraan terus mengalami perkembangan. Termasuk pembagian kekuasaan bertambah menjadi lembaga independen berintegritas. KPK justru dimasukkan dalam rumpun kekuasaan eksekutif. Padahal sebagaimana diketahui bersama bahwa di putusan sebelumnya KPK berada di luar ketiga cabang kekuasaan. MK menantang putusan MK sendiri yang sudah final dan binding. dengan demikian MK perlu memaknai konstitusionalitas pada Pasal 79 ayat (3) UndangUndang Nomor 17 Tahun 2014 Junto Undang-Undang Nomor 13 Tahun 2019 bahwa kewenangan Hak Angket DPR tidak dapat ditujukan untuk menyelidiki KPK. Sebab KPK bukanlah bagian dari eksekutif

Berdasarkan putusan MK pada Tahun 2006 lalu bahwa KPK digolongkan ke dalam lembaga yudikatif yang tidak bisa diberikan hak angket oleh DPR Pasal 79 ayat (3) Undang-Undang Nomor 17 Tahun 2014 Junto Undang-Undang Nomor 13 Tahun 2019 juga perlu ditafsirkan bahwa kewenangan Hak Angket DPR terhadap KPK tidak memenuhi unsur hal penting, strategis dan berdampak luas pada kehidupan bermasyarakat, berbangsa dan bernegara yang diduga bertentangan dengan peraturan perundangan. Pembentukan Hak Angket KPK adalah langkah politis pemohon juga meminta Mahkamah Konstitusi menafsirkan Pasal 199 ayat (3) UU MD3. Sebab pembentukan Hak Angket DPR sendiri diduga kuat bertentangan dengan pasal itu. Maka Untuk menyetujui hak angket tersebut harus dihadiri setengah anggota DPR, yaitu 280. Dari setenga hadir sebagai anggota quorum, harus disetujui oleh setengah anggota yang hadir berdasarkan tertib aturan yang berlaku jadi harusnya yang menyetujui 140 anggota yang hadir. ${ }^{13}$

Hak angket atas KPK menimbulkan pandangan berbeda dari berbagai pihak. Pakar atau pengamat mempunyai pandangan pro dan kontra terhadap keberadaan pansus tersebut. Namun menurut pendapat penulis bahwa dari sisi hukum hak angket tersebut konstitusional. Guna untuk memastikan fungsi-fungsi penyelenggaraan kenegaraan berlangsung akuntabel, transparan, dan dapat dipertanggungjawabkan. Hak angket adalah cara untuk memastikan fungsi-fungsi Negara berlangsung dalam kerangka rule of law. Karena legitimasi eksistensi hak angket jangan dikhawatirkan untuk melemahkan KPK, atau mengintervensi proses penegakan hukum. Pengajuan hak angket justru ingin menguji kejujuran KPK. Oleh karena itu dalam prespektif Negara hukum demokratis hak angket sangat wajar dan biasa saja.

Hak angket DPR terhadap KPK menurut penulis justru tidak ada yang salah dan

12 Ibid, h. 2.

13 Ibid, h. 2.

83 | S A S I Vol. 26 No.1, Januari- Maret 2020 
sudah tepat. Karena KPK itu harus diawasi oleh DPR, Pengawasan itu sama halnya terhadap Kejaksaan Agung (Kejagung) dan kepolisian, dan sebuah kesalahan apabila KPK menolak hak angket tersebut yang digulirkan oleh DPR, mengingat hak angket adalah hak konstitusional DPR yang tercantum dalam Undang-Undang Dasar (UUD) dan UU tentang MPR, DPR, DPD, dan DPRD atau MD3. Oleh karena itu Hak angket yang digulirkan DPR juga berlaku ke semua lembaga atau institusi, dan termasuk KPK. Dengan demikian mengingatkan bahwa KPK itu lembaga diluar konstitusi yang sengaja dibentuk untuk memperbaiki polisi dan kejaksaan, dimana lembaga KPK hanya independen menurut undang-undangnya. DPR justru semakin sah dalam menggulirkan angket jika yang disasar adalah adanya tujuh dugaan penyelewengan anggaran di KPK berdasarkan audit BPK. Soal anggaran di luar perdebatan mengenai boleh tidaknya angket kepada lembaga tersebut. Harusnya dari awal DPR bicarakan hak angket ini ditunjukkan kepada dugaan penyelewengan anggaran jelas. Ini soalnya dikaitkan dengan soal penyadapan oleh pembicaraan saksi.

Di sisi lain Komisi Pemberantasan Korupsi tak perlu khawatir dengan hak angket DPR. Karena saat itu hak angket yang telah disetujui dalam sidang paripurna tidak serta merta mewajibkan KPK untuk membuka rekaman kepada DPR. Meski hak angket merupakan hak konstitusional DPR, menurut Denny Indrayana tetapi juga fungsi pengawasan kekuasaan legislatif terhadap eksekutif. Sementara KPK merupakan lembaga penegak hukum yang independen. Siapapun tidak bisa mencampuri wilayah hukum lembaga penegak hukum manapun. Dalam konteks fungsinya sebagai penegak hukum, KPK termasuk kekuasaan kehakiman yang harus bebas dari segala intervensi dan kekuasaan lain, yaitu eksekutif dan legislatif. Intervensi seperti itu harus ditolak. hal ini dapat meruntuhkan martabat Indonesia sebagai Negara yang berlandaskan hukum. Karena Tindakan tersebut bukan saja pelemahan kepada KPK tapi juga pada kekuasaan kehakiman secara keseluruhan. ${ }^{14}$

Panitia Khusus Hak Angket Komisi Pemberantasan Korupsi yang usai dibentuk Dewan Perwakilan Rakyat saat itu bernafas lega. Karena Di ujung masa tugasnya yang hampir paripurna, legalitas pansus angket tersebut akhirnya mendapatkan pengakuan dari Mahkamah Konstitusi. MK memutuskan menolak permohonan uji materi yang diajukan sejumlah pegawai KPK terhadap Hak Angket KPK. Dengan putusan itu, MK menyatakan hak angket KPK yang dibentuk KPK adalah sah. Tak berubah Meski sudah mendapatkan stempel legal dari MK, sehingga masa kerja Pansus Angket KPK tak akan diperpanjang lagi. Rekomendasi akhir Pansus Angket KPK yang sudah disusun saat itu juga tak akan mengalami perubahan. Dalam rekomendasinya nanti Pansus berencana memperkuat fungsi pencegahan KPK.

Salah satunya dengan meminta komitmen pemerintah untuk memperbesar anggaran pencegahan untuk KPK. Selain itu, Pansus juga ingin menyinergikan KPK dengan penegak hukum lainnya seperti Polri dan Kejaksaan dalam pemberantasan korupsi. Sementara saat itu, rekomendasi akhir yang sudah disusun tidak akan berubah dan masa kerja pansus tak akan diperpanjang. Karena Pansus sudah diputuskan berakhir masa kerjanya, walaupun pimpinan KPK merasa agak kecewa dengan putusannya karena judicial review tersebut di tolak oleh MK. Hal ini di sebabkan, putusan MK yang memposisikan KPK sebagai lembaga yang bisa dapat diangket oleh DPR tak konsisten dan bertentangan dengan empat putusan terdahulu, di mana pada saat itu MK menyatakan bahwa KPK bukan lembaga eksekutif, sehingga menurut penulis keputusan tersebut inkonsistensi.

14 Indrayana, Denny. (2016). Jangan Bunuh KPK, Malang: Intrans Publishing, h. 57-58 
Untuk kelembagaan saat itu, ada tiga rekomendasi Pansus.Yakni menyempurnakan struktur organisasi, kerja sama dengan lembaga lain seperti BPK, LPSK, PPATK, dan Komnas HAM, serta membentuk lembaga pengawas independen.Yang beranggotakan unsur internal KPK dan eksternal yang berasal dari tokoh-tokoh yang berintegritas guna terciptanya check and balances, Di bidang kewenangan, sehingga menurut penulis KPK pentingnya melibatkan polisi dan kejaksaan, memperhatikan aspek hak asasi manusia, dan membangun sistem pencegahan yang bisa membangun budaya malu agar korupsi tak berulang. Di bidang anggaran KPK harus melaksanakan rekomendasi hasil pemeriksaan BPK, mengoptimalkan anggaran pencegahan, sosialisasi, dan kampanye antikorupsi. Di aspek tata kelola sumber daya manusia (SDM), KPK harus memperhatikan tiga undangundang dalam melakukan promosi, mutasi, rotasi dan pemberhentian pegawai, yakni Unadang-Undang Aparatur Sipil Negara, Undang-Undang Kepolisian, dan UndangUndang Kejaksaan.

Putusan Mahkamah Konstitusi terkait Undang-Undang Nomor 17 Tahun 2014 Junto Undang-Undang Nomor 13 Tahun 2019 khususnya terkait hak pansus DPR terhadap KPK tak konsisten. Putusan Nomor 36/PUU-XV/2017 itu juga dianggap bertentangan dengan tiga putusan terdahulu, di mana MK menyatakan bahwa KPK bukan lembaga yang ada di lingkup eksekutif. Putusan terdahulu yang dimaksud antara lain :

1) Putusan Nomor 012-016-019/PUU-IV/2006.

2) Putusan Nomor 5/PUU-IX/2011 dan

3) Putusan Nomor 49/PUU-XI/2013 14 November 2013.

MK pada putusan-putusan MK sebelumnya, Mahkamah tidak pernah menyatakan KPK merupakan lembaga negara yang berada pada ranah kekuasaan tertentu, legislatif, eksekutif, atau yudikatif. Hal ini Penting ditegaskan, baru pada Putusan Nomor 36/PUUXV/2017 tersebut, Mahkamah menyatakan pendapat bahwa KPK merupakan lembaga negara yang berada di ranah kekuasaan eksekutif dalam ketiga putusan sebelumnya. ${ }^{15}$

Mahkamah menyatakan KPK merupakan lembaga negara yang terkait fungsi kekuasaan kehakiman. Posisi KPK sebagai lembaga negara yang bukan termasuk dalam ranah kekuasaaan kehakiman. Namun diberikan tugas, kewenangan, dan fungsi yang berkaitan dengan fungsi kekuasaan kehakiman, Karenanya tidak ada dasar dan alasan untuk menyebut putusan saat ini dengan putusan Mahkamah sebelumnya bertentangan. Justru menurut MK putusan terakhir melengkapi putusan sebelumnya. Bahkan putusan MK terakhir justru menguatkan posisi KPK. Hal ini disebabkan bahwa Hak angket DPR tak bisa dilaksanakan pada wewenang KPK di bidang penyelidikan, penyidikan, dan penuntutan. Sekaligus Mahkamah menguatkan lembaga KPK, karena meskipun menjadi obyek hak angket DPR, akan tetapi hak angket dibatasi bukan pada tugas dan kewenangan yudisial KPK, yaitu penyelidikan, penyidikan, dan penuntutan dalam perkara dugaan tindak pidana korupsi.

KPK yang sejak awal menolak keberadaan panitia angket merespons rekomendasi yang dihasilkan DPR itu dengan menyatakan tidak setuju dengan beberapa poin dalam rekomendasi. KPK menghormati fungsi pengawasan DPR dalam konteks hubungan kelembagaan. Tanggung jawab pemberantasan korupsi termasuk indeks persepsi korupsi (IPK) Indonesia merupakan tanggung jawab DPR dan pemerintah juga sikap KPK yang dibacakan di paripurna DPR. KPK sangat terbuka dengan evaluasi dan pengawasan, serta mengajak DPR melakukan hal-hal yang lebih substansial dan berdampak luas bagi

15 Lihat Putusan MK Nomor 012-016-1019/PUU-IV/2006, dan Putusan MK Nomor 36/PUUXV/2017. H. 268. 
kebaikan masyarakat. Sejalan dengan itu, KPK juga berharap DPR melakukan evaluasi karena banyak koruptor yang berasal dari lembaga legislatif. Bahkan anggota legislatif menempati urutan ketiga; swasta (184), eselon I-III (175), dan DPRD/DPRD (144).

Sebelumnya juga sudah ada setidaknya empat putusan MK yang menegaskan bahwa KPK bukanlah bagian dari eksekutif. Jadi putusan MK kemarin itu bertentangan dengan putusan-putusan sebelumnya Putusan yang dimaksud adalah putusan atas perkara nomor 012-016-019/PUU-IV/2006, 19/PUU-V/2007, 37-39/PUU-VIII/2010, dan Nomor 5/PUU-IX/2011. Empat putusan tersebut juga disinggung oleh empat hakim MK yang menyatakan disssenting opinion atau perbedaan pendapat dalam sidang putusan kemarin. Pada intinya keempat putusan itu menegaskan, KPK merupakan lembaga independen yang bukan berada di dalam ranah eksekutif, legislatif, dan yudikatif. Dan putusanputusan itu sifatnya inkrah juga dalam pembuatan sebuah undang-undang, jadi UndangUndang yang baru dibentuk bisa menghapus Undang-Undang lama. Namun hal serupa tidak berlaku di pengadilan karena putusan lama itu tak bisa dihapus dengan putusan baru.

Menurut Moh. Mahfud MD, yang berlaku itu yang pertama karena sudah inkrah, pansus Angket KPK yang dibentuk DPR tak bisa menggunakan putusan MK terbaru tersebut sebagai legitimasi. Sebab saat pansus dibentuk masih berlaku putusan MK sebelumnya dimana KPK. Panitia Khusus Angket Komisi Pemberantasan Korupsi yang dibentuk Dewan Perwakilan Rakyat saat itu tetap tidak sah, meski MK sudah mengeluarkan putusan yang menegaskan bahwa KPK termasuk lembaga eksekutif yang dapat menjadi obyek hak angket DPR. Namun putusan MK tersebut tidak berarti apa-apa. Sebab pembentukan Pansus Angket KPK sendiri telah melanggar ketentuan yang ada dalam Undang-Undang Nomor 17 Tahun 2014 Junto Undang-Undang Nomor 13 Tahun 2019 tentang MPR, DPR, DPD dan DPRD. Pasal 201 Ayat (2) yang menyebutkan bahwa keanggotaan Pansus Angket terdiri dari semua unsur fraksi yang ada di DPR. ${ }^{16}$

Putusan Mahkamah Konstitusi terkait hak angket DPR terhadap KPK akan menjadi insiden buruk. Dalam putusannya MK menyatakan bahwa KPK merupakan bagian dari eksekutif sehingga bisa menjadi objek hak angket. Implikasi putusan ini, jika ada tindakan KPK yang tak disukai DPR, sewaktu-waktu hak angket tersebut bisa dikeluarkan lagi. Karena Akibat lanjutan dari putusan MK ini, KPK menjadi rentan yang setiap saat bisa diganggu oleh angket DPR, berdasarkan Pasal 79 ayat (3) Undang-Undang Nomor 17 Tahun 2014 Junto Undang-Undang Nomor 13 Tahun 2019, objek hak angket adalah pelaksanaan suatu undang-undang dan atau kebijakan pemerintah yang berkaitan dengan hal penting, strategis, dan berdampak luas pada kehidupan bermasyarakat, berbangsa, dan bernegara yang diduga bertentangan dengan peraturan perundang-undangan. Putusan tersebut dinilainya ambigu dan inkonsisten dengan putusan MK sebelumnya.

Menurut penulis bahwa, hal ini sangat mungkin pengaruh dari kualitas hakimhakimnya sebelumnya, karena dalam pertimbangannya, MK menyatakan bahwa KPK adalah lembaga penunjang pemerintah yang dibentuk berdasarkan Undang-Undang. Dengan demikian, KPK adalah lembaga eksekutif. KPK merupakan lembaga di ranah eksekutif yang melaksanakan fungsi eksekutif yakni penyidikan dan penuntutan. Oleh karena itu DPR berhak meminta tanggung jawab KPK Dari sembilan hakim, ada empat hakim yang menyatakan disssenting opinion atau perbedaan pendapat atas putusan tersebut. Maka dengan demikian KPK tetap harus menghormati putusan MK itu. KPK membaca ada satu penegasan penting di pertimbangan hakim, yaitu mengecualikan ruang lingkup tugas pengawasan DPR terhadap KPK, khususnya yang menyangkut pelaksanaan tugas yudisial (penyelidikan, penyidikan dan penuntutan. Artinya, tugas yudisial KPK

16 MD, Mahfud Loc. Cit.

86 | S A S I Vol. 26 No.1, Januari- Maret 2020 
dilakukan di koridor hukum saja dan tidak termasuk ranah pengawasan DPR, karena fungsi pengawasan terhadap tugas penegakan hukum sudah diatur sesuai mekanisme hukum acara yang berlaku.

\section{PE N U T P}

Berdasarkan uraian diatas maka penulis menarik kesimpulan sebagai berikut,1). Fungsi pengawasan DPR melalui hak angket adalah hak DPR untuk melakukan penyelidikan terhadap pelaksanaan suatu Undang-Undang dan/atau kebijakan Pemerintah, yang berkaitan dengan hal penting strategis, dan berdampak luas pada kehidupan bermasyarakat, berbangsa, dan bernegara yang diduga bertentangan dengan Peraturan perundang-undangan. Sehingga secara jelas hal tersebut merupakan dibatasi dalam pelaksanaan suatu Undang-Undang dan/atau kebijakan Pemerintah yang dilaksanakan sendiri oleh Presiden, Wakil Presiden, Menteri Negara, Panglima TNI, Kapolri, Jaksa Agung, atau Pimpinan Lembaga Pemerintah nonkementerian, 2). KPK merupakan komisi Negara independen yang menurut perspektif Hukum Tata Negara Modern adalah lembaga Negara yang tidak termasuk cabang kekuasaan eksekutif dan karenanya tidak berada dibawah kontrol Presiden. Komisi negara independen adalah organ Negara yang diidealkan independen dan karenanya berada di luar cabang kekuasaan eksekutif, legislatif maupun yudikatif, dengan tetaplah memunyai fungsi campur dari ketiganya. Namun dengan adanya Putusan Mahkamah Konstitusi Nomor 36/PUU-XV/2017, maka KPK menjadi objek dari hak angket DPR dalam fungsi pengawasannya dan masuk dalam rumpun Eksekutif. Dan 3). Pemahaman bahwa penggunanaan hak angket DPR bukan tanpa batas. Artinya ada batasan-batasan tertentu dalam mempergunakan hak angket DPR tersebut, dimana khusus untuk hak angket terhadap KPK, Putusan Nomor 36/PUU$\mathrm{XV} / 2017$ telah memberikan batas untuk tidak memasuki wilayah yudisial, yaitu penyelidikan, penyidikan dan penuntutan. Karena itu, jika terjadi kembali penggunaan hak angket terhadap KPK, maka Panitia Angket tidak dapat memasuki Hak Angket DPR, KPK dan Pemberantasan Korupsi wilayah yudisial tersebut.

Berdasarkan pembahasan dan kesimpulan yang telah dikemukakan di atas, maka saran saya adalah walaupun Hak angket telah di gulirkan oleh DPR dan dengan adanya Putusan MK menjadikan KPK berada pada rumpun kekuasaan Eksekutif, namun pentingnya organ DPR dan KPK harus bermitra untuk memberantas korupsi di Indonesia. Selain itu DPR harus mendukung KPK dari sisi anggaran yang lebih cukup melalaui program legislasi guna untuk menyelesaikan agenda-agenda Korupsi yang hingga saat ini belum tuntas di seluruh penjuru Indonesia.

\section{DAFTAR PUSTAKA}

\section{Buku}

[1] Logemann, J.H.A, (1985). Over De Theorie Van Enn Stelling Staatrecht, Jogyakarta : Gajah Mada.

[2] Isra, Saldi. (2010). Pergeseran Fungsi Legislatif Menguatnya Model Legislasi Parlementer Dalam Sistem Presidensial Indonesia, Jakarta: Raja Grafindo Persada.

[3] Manan, Bagir. (2005). DPR, DPD, dan MPR dalam UUD 1945 Baru, Yogyakarta: FH-UII Press.

[4] Soemantri, Sri. (1993). Tentang Lembaga-lembaga Negara Menurut UUD 1945, Bandung: Citra Aditya Bakti. 
[5] Arifin, Firmansyah, dkk. (2005). Lembaga Negara dan Sengketa Kewenangan Antar Lembaga Negara, Jakarta: Konsorsium Reformasi Hukum Nasional.

[6] Indrayana, Denny. (2016). Jangan Bunuh KPK, Malang: Intrans Publishing.

[7] Alrasid, Harun. (1999). Pengisian Jabatan Presiden, Jakarta: Pustaka Utama Grafiti.

[8] Wahyudi, Zaid. (2017). Penyelagunaan Kekuasaan: Gagalnya Sistem Kendali Diri, Rumah Pengatahuan. Jakarta: Rajawali Pers.

[9] S.S.T, Arifin. (1998). Fungsi Dewan Perwakilan Rakyat Republik Indonesia Menurut UUD 1945, Suatu Studi Analisis Mengenai Pengaturannya Tahun 19661997. Jakarta: Sekolah Tinggi.

\section{Jurnal dan Lain-Lain}

[10] Asshiddiqie, Jimly. (2013). Struktur Ketatanegaraan Indonesia Setelah Perubahan Keempat UUD Tahun 1945, Makalah dalam seminar Pembangunan Hukum Nasional VIII, Denpasar 14-18 Juli 2013.

[11] Manan, Bagir. (2018). Hak Angket Sebagai Kekuasaan Pengawasan DPR. Jurnal Varia Peradilan XXXIII (387): 6-23.

[12] Hak Angket DPR, KPK dan Pemberantasan Korupsi 126 | Volume 4 Nomor 2, Desember 2018

[13] Miranda, R.A. (2009). Kedudukan Komisi Independen Sebagai Auxiliary Institutions dan Relevansinya Dalam Struktur Ketatanegaraan Indonesia. Jurnal Konstitusi, kerja sama MK dan PSKN FH Universitas Padjadjaran 1 (1): 53-71. KPK. 2018. Tanggapan KPK Atas 10 Rekomendasi Pansus Hak Angket DPR.

[14] https://kumparan.com/@kumparan-news/tanggapan-kpk-atas-10-rekomendasipansus-hak angket-dpr. 28 Juli 2018 (22.30). KPK. 2018. KPK Sebut Lembaga Pengawas Usulan Pansus Angket Mengada-ada.

[15] Teori dan Politik Konstitusi, Yogyakarta: FH UII Press. DPR. 2017. Paripurna DPR Sahkan Usulan Hak Angket KPK.

[16] http://www.berita-satu.com/nasional-kpk/427713-paripurna-dprsahkan-usulan-hakangket kpk. html. 20 Juli 2018 (19.05). DPR. 2017. Ini Sederet Alasan DPR Gulirkan Hak Angket KPK.

[17] https://news.detik.com/berita/d3486828/ini-sederet-alasandpr-gulirkan-hak-angketkpk. 15 Juli 2018 (15.00). DPR. 2018. Empat Rekomendasi Pansus Angket DPR Untuk KPK.

[18] http://www.tribunnews.com/nasional/2018/02/14/empatrekomendasi-pansusangket-dpr-Laporan Panitia Angket DPR RI Tentang Pelaksanaan Tugas dan Kewenangan Komisi Pemberantasan Korupsi Yang Diatur Dalam Undang-Undang Nomor 30 Tahun 2002 tentang Komisi Pemberantasan Tindak Pidana Korupsi.

[19] Soerjono, S. 2007. Pengantar Penelitian Hukum, UI Press, Jakarta.

[20] Yusril, I.M. 2018. Menurut Yusril Hak Angket Bisa Ditujukan Untuk Semua Lembaga. https://nasional.kompas.com/read/2017/09/14/17595501/menurut-yusrilhak-ang-ket bisaditujukan-untuk-semua-lembaga. 15 Juli 2018 (20.00).

[21] Hak Angket DPR, KPK dan Pemberantasan Korupsi Volume 4 Nomor 2, Desember 2018 | 127 Peraturan Perundangan-Undangan dan Putusan Hakim. 